\title{
Over-expression of Gadd45a enhances radiotherapy efficacy in human Tca8113 cell line
}

\author{
Xiao-ying ZHANG ${ }^{1,2}$, Xun QU ${ }^{3}$, Cheng-qin WANG ${ }^{1}$, Cheng-jun ZHOU ${ }^{1}$, Gui-xiang LIU $^{1}$, Feng-cai WEI ${ }^{2}$, Shan-zhen SUN ${ }^{1, *}$ \\ ${ }^{1}$ Department of Pathology, the School of Stomatology, Shandong University, Ji-nan 250012, China; ${ }^{2}$ Department of Stomatology, Qilu \\ Hospital, Shandong University, Ji-nan 250012, China; ${ }^{3}$ Institute of Basic Medical Sciences, Qilu Hospital, Shandong University, Ji-nan \\ 250012, China
}

\begin{abstract}
Aim: To investigate the effect of the growth arrest- and DNA damage-inducible Gadd45a gene on the radiosensitivity of human tongue squamous cell carcinoma cell line to ionizing radiation (IR).

Methods: Short interfering ribonucleic acid (si-RNA) targeting Gadd45a or an irrelevant mRNA (nonsense si-RNA) was chemically synthesized. The constructed si-RNAs were transfected into Tca8113 cells and Gadd45a expression was determined using quantitative real-time PCR and Western-blot. After 24-h exposure to IR at a dose rate of $4 \mathrm{~Gy} / \mathrm{min}$, apoptosis of Tca8113 cells was detected using flow cytometry, and radiosensitivity was measured using MTT assays.

Results: IR apparently increased the expression of Gadd45a at mRNA and protein levels in Tca8113 cells. The effect was efficiently inhibited by transfection with Gadd45a si-RNA $(P<0.01)$. Furthermore, silencing Gadd45a gene significantly increased cell viability and decreased the percentage of apoptotic cells during irradiation, which indicated that IR-induced Gadd45a over-expression could increase the radiosensitivity of Tca8113 cells.

Conclusion: These results indicated that targeting Gadd45a may have important therapeutic implications in sensitizing Tca8113 cells to IR.
\end{abstract}

Keywords: ionizing radiation; Gadd45a; squamous cell carcinoma; Tca8113 cells; apoptosis; RNA interference

Acta Pharmacologica Sinica (2011) 32: 253-258; doi: 10.1038/aps.2010.208

\section{Introduction}

Oral squamous cell carcinoma (SCC) is one of the most frequently diagnosed tumors of the head and neck ${ }^{[1,2]}$. Despite improvements in treatment, the survival rates of patients with oral SCC have not been significantly improved over the past several decades.

Radiotherapy is one of the most commonly used treatments for cancer patients. The responses of tumor cells to ionizing radiation (IR) are often tissue specific. Some data have confirmed that postoperative radiotherapy (PORT) improved regional control of pathologic N1 neck disease ${ }^{[3]}$. Identifying molecules and mechanisms that sensitize tumor cells to IR will provide new potential therapeutic strategies for cancer treatment.

The growth arrest- and DNA damage-inducible (gadd) 45 gene family, comprising gadd $45 \alpha /$ gadd $45 a$, gadd $45 \beta /$ gadd $45 b /$ myd118, and gadd45 $/ \mathrm{gadd} 45 \mathrm{~g} / \mathrm{cr} 6$, is widely expressed in mam-

\footnotetext{
* To whom correspondence should be addressed.

E-mail leaf_zi@126.com

Received 2010-06-12 Accepted 2010-11-14
}

malian cells responding to stress stimuli ${ }^{[4]}$. Gadd45a gene was initially isolated from Chinese Hamster Ovarian cells (CHO) treated with ultraviolet radiation ${ }^{[5]}$. Subsequently, it was found to be induced by a wide spectrum of DNA-damaging agents and growth arrest treatments such as $\mathrm{IR}^{[6]}$, methylmethane sulfonate (MMS) ${ }^{[7]}$, growth factor withdrawal ${ }^{[8]}$, hydrogen peroxide ${ }^{[9]}$, hypoxia and many cancer chemotherapeutic drugs ${ }^{[10]}$. For over one decade, the mechanisms of Gadd45a induction have been the focus of study. Gadd45a was the first stress-inducible gene determined to be up-regulated by p53 and is also a target for the p53 homologues, p63 and p73 ${ }^{[11]}$. Among p53-regulated genes, Gadd45a has been shown to play an important role in DNA damage-induced cell responses. For example, Gadd45a deficiency caused defective UV-induced nucleotide excision repair ${ }^{[12]}$. The embryonic fibroblast cells in Gadd45a-null mouse exhibited increased aneuploidy accompanied with abnormal centromere amplification; after exposure to IR, Gadd45a-null mice also showed increased carcinogenesis compared with control mice ${ }^{[13]}$. In addition to p53, BRCA1 and FOXO3a have also been shown to activate Gadd45a gene expression ${ }^{[14,15]}$. Furthermore, Gadd45a 
is also involved in DNA damage-induced apoptosis. Gadd45a suppresses Ras-induced mammary tumorigenesis by activation of p38 stress signaling and induces apoptosis of HeLa cells by promoting Bim translocation to mitochondria ${ }^{[16,17]}$. However, little is known about the role of Gadd45a in control of apoptosis in the cell response to IR in vitro.

In the present study, we investigated the induction of Gadd45a gene expression following irradiation in Tca8113 cells, and assessed its effect on the sensitivity of Tca8113 cells line to IR treatment.

\section{Materials and methods Cell culture}

Tca8113 cell line was purchased from Culture Collection of Chinese Academy of Science (Shanghai, China) and routinely cultured in Dulbecco's modified Eagle's medium (DMEM, Gibco) supplemented with $10 \%$ fetal bovine serum (Gibco) at $37^{\circ} \mathrm{C}$ in a humidified air atmosphere containing $5 \% \mathrm{CO}_{2}$.

\section{lonizing radiation (IR)}

Tca8113 cells were cultured in six-well plates until 70\% confluence and then exposed to IR from a VARIAN clinical 2100C/D linear accelerator (VARIAN, Palo Alto, CA, USA) at a dose rate of $4 \mathrm{~Gy} / \mathrm{min}$.

\section{Gene silencing with si-RNA}

Tca8113 cells were divided into three groups for transfection: lipofectamine ${ }^{\mathrm{TM}} 2000$ only (mock), nonsense si-RNA or Gadd45a si-RNA. Mock and nonsense si-RNA (Gene Chem, China) were regarded as control groups. Tca8113 cells were planted in six-well plates. The cells reached $40 \%$ confluence, and then the media was changed to opti-MEM (Invitrogen, USA). The cells were transfected with the Gadd45a si-RNA or control si-RNA $(100 \mathrm{nmol} / \mathrm{L})$ premixed with the lipofectamine $^{\mathrm{TM}} 2000$ (Invitrogen, USA) in Opti-MEM. At $6 \mathrm{~h}$ after transfection, the cells were placed in fresh complete medium without penicillin and streptomycin. The sequences of Gadd45a si-RNA and nonsense si-RNA were listed in Table 1.

Table 1. Si-RNA sequences for gene silencing.

\begin{tabular}{ll}
\hline Gene name & \multicolumn{1}{c}{ Si-RNA sequences } \\
\hline \multirow{2}{*}{ Gadd45a } & Sense, 5'-3'CACTGATGCAAGGATTACA \\
& Antisense, 5'-3'TGTAATCCTTGCATCAGTG \\
Nonsense & Sense, 5'-3'UUCUCCGAACGUGUCACGUtt \\
& Antisense, 5'-3'ACGUGACACGUUCGGAGAAtt \\
\hline
\end{tabular}

\section{Quantitative real-time RT-PCR analysis for Gadd45a}

Total RNA was extracted from Tca8113 cells using the Trizol (Invitrogen, USA) method as recommended by the manufacturer. The quantity and concentration of the purified RNA were assessed by 260/280 optical density (OD) measurements on a spectrophotometer (Biochrom, USA). An equal amount of RNA was reverse transcribed with the First Strand cDNA Synthesis kit (Fermentas, EU). To determine the level of Gadd45a mRNA, real time quantitative PCR analysis was performed with Light Cycler 2.0 (Roche Diagnostics, Switzerland) according to the protocol recommended by TaKaRa SYBR_ Premix Ex Taq ${ }^{\mathrm{TM}}$ (TaKaRa, Japan). Thermal cycling parameters were as follows: an initial incubation of $95^{\circ} \mathrm{C}$ for $30 \mathrm{~s}$, and then 40 cycles of $95^{\circ} \mathrm{C}$ for $5 \mathrm{~s}$ and $55^{\circ} \mathrm{C}$ for $20 \mathrm{~s}$ and $72{ }^{\circ} \mathrm{C}$ for 15 s. The Gadd45a mRNA expression level was normalized to the median expression of $\beta$-actin. Gene-specific forward $(F)$ and reverse $(R)$ primer sequences for Gadd45a and $\beta$-actin were summarized in Table 2.

Table 2. Primer sequences of Gadd45a for quantitative real time RT-PCR.

\begin{tabular}{lc}
\hline Gene name & \multicolumn{1}{c}{ Primer sequences } \\
\hline \multirow{2}{*}{ Gadd45a } & F: 5'-CGT TTT GCT GCG AGA ACG AC-3' \\
\multirow{3}{*}{ R-actin } & R: 5'-GAA CCC ATT GAT CCA TGT AG-3' \\
& F: 5'-AGC GAG CAT CCC CCA AAG TT-3' \\
& R: 5'-GGG CAC GAA GGC TCA TCA TT-3' \\
\hline
\end{tabular}

\section{Protein extraction and Western blot analysis}

Cellular protein extracts were prepared by homogenization in an ice-cold buffer [50 mmol/L Tris- $\mathrm{HCl}$ (pH 7.4), $150 \mathrm{mmol} / \mathrm{L}$ $\mathrm{NaCl}, 1 \%$ Triton X-100, 2 mmol/L EDTA (pH 8.0), $2 \mu \mathrm{g} / \mathrm{mL}$ aprotinin, $5 \mathrm{mmol} / \mathrm{L}$ dithiothreitol and $0.2 \mathrm{mmol} / \mathrm{L}$ phenylmethylsulphonyl fluoride, $1 \mathrm{mmol} / \mathrm{L}$ PMSF, $10 \mu \mathrm{g} / \mathrm{mL}$ leupeptin] for $30 \mathrm{~min}$. The lysates were centrifuged at $15000 \times g$ for $15 \mathrm{~min}$ at $4{ }^{\circ} \mathrm{C}$ and protein concentrations of the supernatants were determined by BCA protein assay kit (Calbiochem, USA). Equivalent amount of protein $(80 \mu \mathrm{g})$ was electrophoresed on a $12 \%$ polyacrylamide gel and electrotransferred onto Immobilon-P (Millipore). After being blocked with 5\% non-fat milk, the membrane was incubated overnight at $4{ }^{\circ} \mathrm{C}$ with rabbit polyclonal anti-human Gadd45a antibodies (dilution 1:500, Millipore; 07-1230), then washed and incubated with goat polyclonal anti-rabbit HRP-labeled secondary antibody (Santa Cruz, CA) in TBST (TBS containing 0.05\% Tween 20) for $2 \mathrm{~h}$. The bands were detected by enhanced chemiluminescence (ECL). The intensities of acquired bands were measured by computerized image analysis and normalized to tubulin as the internal control.

\section{MTT assays for determination of cellular viability}

The antiproliferative effect of Gadd45a gene was evaluated using the MTT assay as described by Azria ${ }^{[18]}$. Exponentially growing cells were seeded into 96-well plates (6 000/well) and transfected as mentioned above. Tca8113 cells transfected with the Gadd45a si-RNA and the control cells were irradiated in the dose range from 0 to $10 \mathrm{~Gy}$. After 24-h exposure to IR, the viability of the cells was analyzed using MTT colorimetric assay. MTT was a pale yellow tetrazolium salt that produces a dark blue formazan product when incubated with the living 
cells. Briefly, $20 \mu \mathrm{L}$ of $0.5 \%$ MTT solution was added to each well and was incubated with the cells for $4 \mathrm{~h}$ at $37^{\circ} \mathrm{C}$ to allow crystal formation. The medium was decanted and the crystals were dissolved by adding dimethyl sulphoxide (DMSO; $200 \mu \mathrm{L} /$ well). The absorbance at $490 \mathrm{~nm}$ was measured using ELISA Reader (RT-2100C, Rayto, USA). The results were expressed with respect to control values (cells without any treatment). Experiments were repeated three times.

\section{Detection of apoptosis by flow cytometry}

Apoptosis rates of the experimental group and the control groups were measured with AnnexinV-FITC kit (BD Biosciences, San Diego, CA, USA) by flow cytometry according to the manufacturer's instructions. At $24 \mathrm{~h}$ after radiation exposure to $4 \mathrm{~Gy}$ or $10 \mathrm{~Gy}$, the cells were harvested by trypsinization and washed twice with ice-cold PBS and resuspended in binding buffer. A total of $5 \mu \mathrm{L}$ of Annexin V-FITC and $10 \mu \mathrm{L}$ of propidium iodide (PI) were added to cell suspensions. After incubation for $15 \mathrm{~min}$ at room temperature in the dark, $400 \mu \mathrm{L}$ of binding buffer was added to the mixture. The cells were analyzed by flow cytometry (Becton Dickinson, USA) and the data were analyzed with WinMDI 2.8 software for calculation of percentage of apoptotic cells.

\section{Statistical analysis}

Statistical analysis was performed using SPSS 17.0 version software package for Windows. All values were presented as mean \pm standard deviation (SD) of replicate samples in single experiments or replicate experiments. The $t$ test was used to analyze the data. Differences were considered statistically significant at $P<0.05$.

\section{Results}

Basal and IR-induced Gadd45a expression in Tca8113 cells

We initially examined the effect of IR on Gadd45a expression in human Tca8113 cell lines by quantitative real-time RT-PCR and Western blot analysis. Gadd45a induction was assessed by comparing the basal level to that present $24 \mathrm{~h}$ following treatment with 4 Gy or 10 Gy IR. As shown in Figure 1A, IR obviously induced Gadd45a mRNA expression compared with the basal level $(0.000965 \pm 0.00005$ vs $0.000387 \pm 0.00002$ and $0.001644 \pm 0.000065$ vs $0.000387 \pm 0.00002$ ) in the dose range examined. Consistently, Gadd45a protein level detected by Western blot was also induced by 10 Gy IR $(P=0.0028)$ although Gadd45a protein level observed in Tca8113 cells treated with 4 Gy IR had no statistical difference in comparison with the basal level ( $P=0.0513$, Figure 1B).

\section{Gadd45a si-RNA suppressed the expression of Gadd45a}

Quantitative real-time RT-PCR and Western blot were performed to determine whether the expression of Gadd45a mRNA and protein were knocked down by Gadd45a siRNA. The levels of Gadd45a mRNA and Gadd45a protein in the group transfected with Gadd45a si-RNA were significantly decreased compared with the control groups $(P<0.01)$,

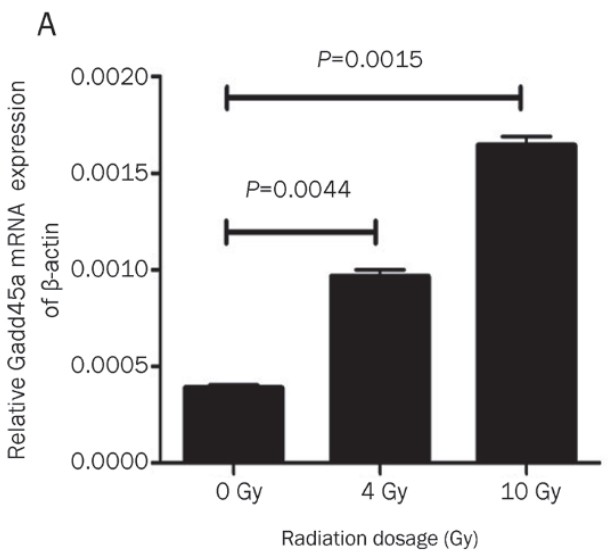

B
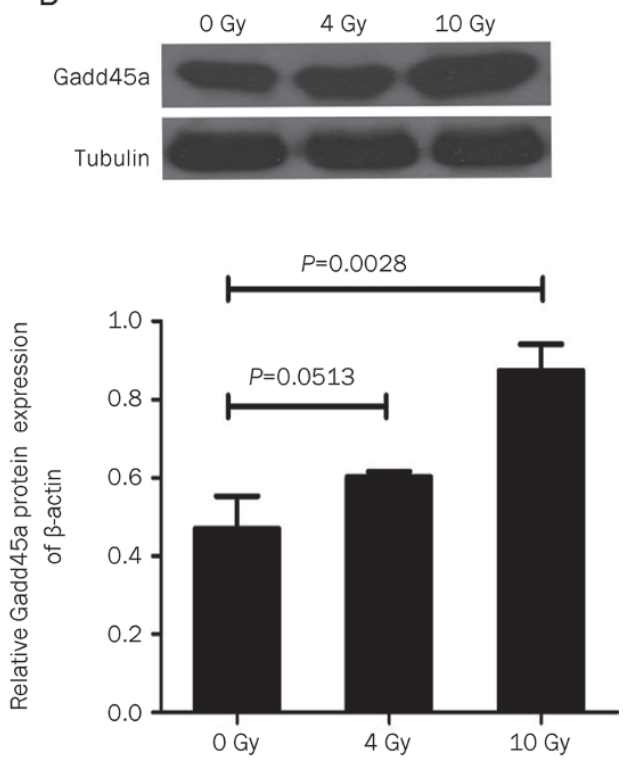

Figure 1. Over-expression of Gadd45a in Tca8113 cells was induced by IR. (A) The level of Gadd45a mRNA after 24-h exposure to IR at 4 or 10 Gy was significantly higher than the basal level $(P<0.01)$. (B) Over-expression of Gadd45a protein was not significantly induced in Tca8113 cells after exposure to 4 Gy IR $(P=0.0513)$, but was markedly induced after exposure to 10 Gy IR $(P=0.0028)$. $n=3$. Mean \pm SD.

demonstrating that the expression of Gadd45a was effectively restrained by si-RNA (Figure 2). Although Tca8113 cells transfected with Gadd45a si-RNA had an increase in Gadd45a mRNA expression following treatment with $10 \mathrm{~Gy}$ IR $(P=0.0489)$, the level of Gadd45a protein was not markedly elevated $(P=0.0566)$.

\section{Gadd45a si-RNA inhibited the radiosensitivity of Tca8113 cells} MTT assays were used to examine the effects of Gadd45a siRNA on the radiosensitivity of Tca8113 cells. As shown in Figure 3, irradiation resulted in a dose-dependent reduction in cell survival fraction, and the effect was significantly inhibited in the cells transfected with Gadd45a si-RNA compared with nonspecific control cells $(P<0.05)$. 


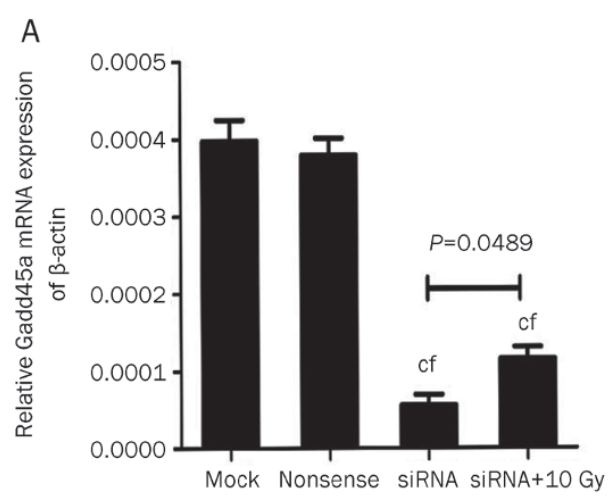

B
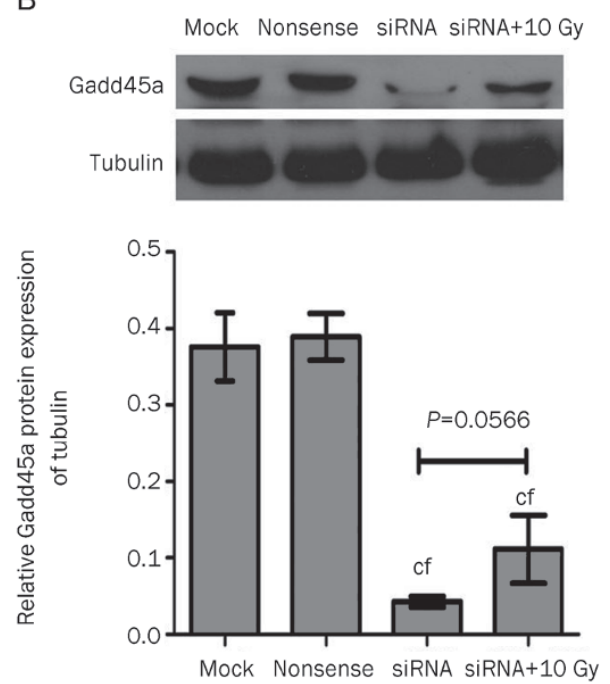

Figure 2. Inhibitive effect of si-RNA on Gadd45a expression in Tca8113 cells. (A) The results of quantitative real-time PCR demonstrated that the expression of Gadd45a mRNA in si-RNA and si-RNA+10 Gy groups was significantly lower than that in the control groups. (B) The expression of Gadd45a protein was apparently inhibited in the Tca8113 cells transfected with Gadd45a si-RNA. $n=3$. Mean \pm SD. ${ }^{c} P<0.01$ vs mock. ${ }^{\mathrm{f}} P<0.01$ vs nonsense.

IR-induced over-expression of Gadd45a increased the apoptosis of Tca8113 cells

To determine whether the increased expression of Gadd45a modulated the apoptosis of Tca8113 cells exposed to IR, flow cytometry measurement was used to quantify the percentage of apoptotic cells in the total cell population. After 24-h exposure to 4 or 10 Gy radiation, a significantly lower percentage of apoptotic cells was observed in Tca8113 cells transfected with Gadd45a si-RNA than the other groups $(P<0.01$, Figure 4$)$.

\section{Discussion}

Squamous cell carcinoma (SCC) accounts for more than 90\% of malignancies of the oral cavity and oropharyn $x^{[19]}$. Patients with SCC are generally treated with surgery in combination with radiotherapy ${ }^{[20,21]}$. However, permanent xerostomia is a common complication of radiation therapy for head and neck

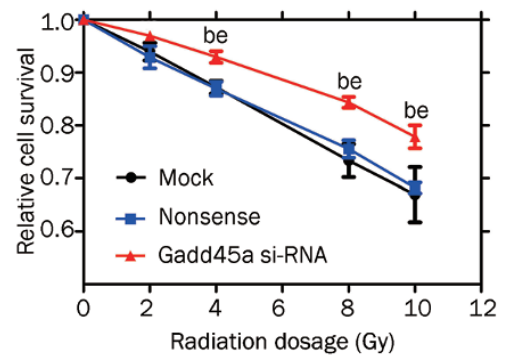

Figure 3. Effect of Gadd45a silencing on the radiosensitivity of Tca8113 cells. Tca8113 cells transfected with the Gadd45a si-RNA and the control cells were seeded into 96-well plates and irradiated in the dose range from 0 to 10 Gy. After 24 h, the viability of the cells was analyzed using MTT assay. When the dose was 4 Gy or more, there was significant difference in the survival level between the cells transfected with Gadd45a si-RNA and the control cells. $n=3$. Mean \pm SD. ${ }^{\mathrm{b}} P<0.05$ vs mock. ${ }^{\mathrm{e}} \mathrm{P}<0.05$ vs nonsense.
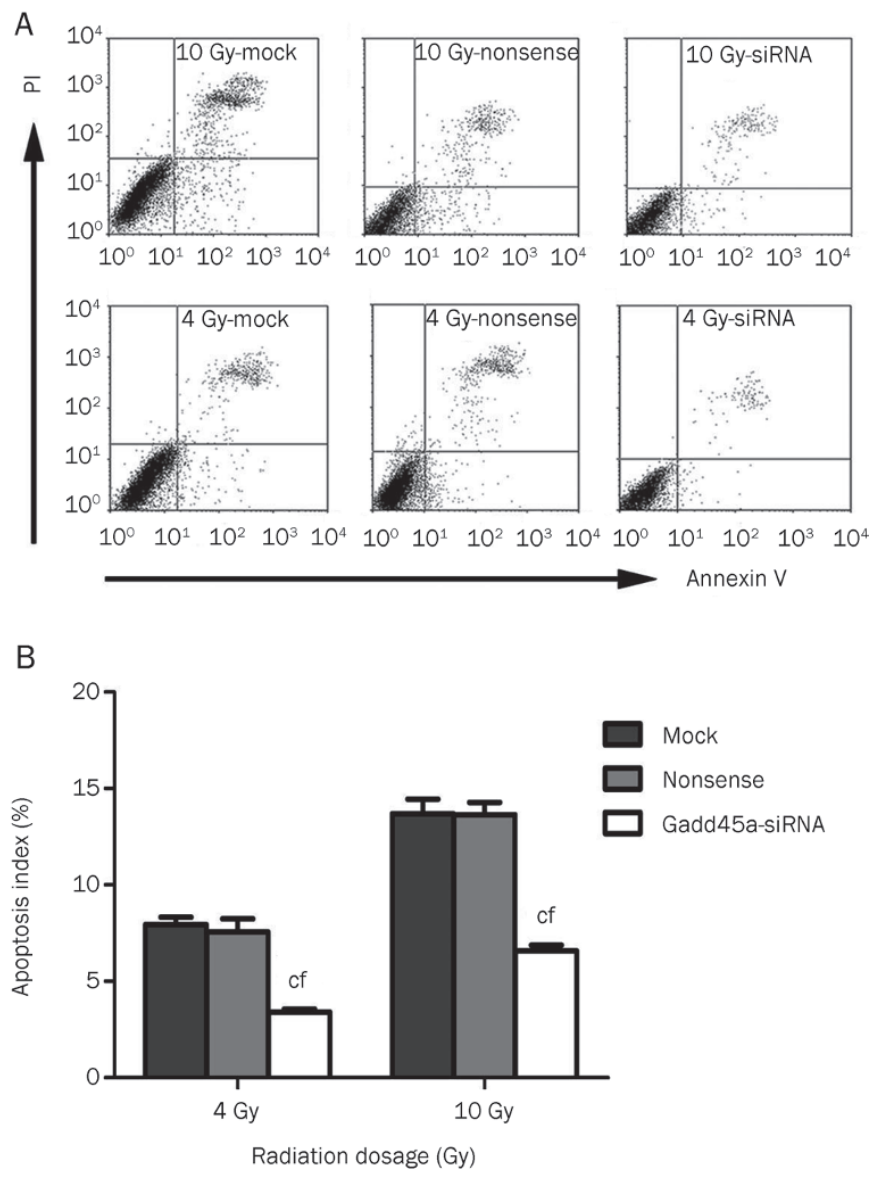

Figure 4. Gadd45a si-RNA reduced the apoptosis of Tca8113 cells after radiotherapy. (A) Tca8113 cells were harvested for apoptosis analysis at $24 \mathrm{~h}$ after 4 Gy or 10 Gy IR. Flow cytometry was used to examine the percentage of apoptosis cells. (B) The results of flow cytometry analysis showed that Gadd45a knockdown caused a significant inhibition of apoptosis induced by IR treatment. $n=3$. Mean \pm SD. ${ }^{C} P<0.01$ vs mock. ${ }^{\mathrm{f}} P<0.01$ vs nonsense. 
cancer, reducing the patient's quality of life ${ }^{[22]}$. Therefore, it is essential to develop more effective radiotherapy regimens for oral SCC.

The responses of tumor cells to IR are often closely related to pathway aberrations present in tumors. The Gadd45a gene is a member of a group of genes that have been characterized as important players that participate in cellular response to a variety of DNA damage agents ${ }^{[23]}$. In previous studies, the human Gadd45a has been found to be strongly and rapidly induced by $X$ rays $^{[6,24]}$. In the present study, we explored the induction of Gadd45a gene in Tca8113 cell line. At $24 \mathrm{~h}$ after radiation treatment, the levels of Gadd45a mRNA and protein in Tca8113 cells were markedly up-regulated than the baseline level and graded doses of radiation produced obviously linear increases of Gadd45a mRNA in the dose range examined. These results implied that the induction of Gadd45a by IR in Tca8113 cells was specific and long-lasting. Similar results have also been shown in human myeloblastic leukemia ML-1 cells $^{[25]}$.

Gadd45a was primarily considered as a pro-apoptotic gene, and has been reported as being able to activate the mitochondrial pathway of apoptosis ${ }^{[26]}$. It has been reported that knockdown of Gadd45a led to increased growth and survival of FDB1 myeloid cells ${ }^{[27]}$. Moreover, Zhang et al found that high level expression of Gadd45a sensitized M1 myeloblastic leukemia and H1299 lung carcinoma cell lines to apoptosis induced by gamma-irradiation ${ }^{[28}$. However, inactivation of Gadd45a gene has been reported to sensitize transgenic tumor mouse to radiation treatment ${ }^{[29]}$. In the current study, we further reveal the role of Gadd45a in the response of oral cancer cells to IR treatment using si-RNA. This approach has been used previously in other cell types, and gene silencing of Gadd45a led to disruption of functions including its ability to induce apoptosis ${ }^{[30,31]}$. We showed that Gadd45a si-RNA specifically repressed Gadd45a expression, and the inhibition reduced cell apoptosis and enhanced proliferation of Tca8113 cells after exposure to radiation. Our results demonstrated that Gadd45a inactivation reduced the sensitivity of Tca8113 cells to IR and the high level Gadd45a expression induced by IR might contribute to apoptosis of oral cancer cells. The gene therapy targeting Gadd45a in tumor cells could have important implications for the development of novel strategies in radiotherapy of oral SCC.

In conclusion, the results not only provided a better understanding of the biological function of Gadd45a but also suggested that Gadd45a might be a critical target for enhancing radiosensitivity of oral SCC. Although Gadd45a expression is correlated with the apoptosis induced by IR in Tca8113 cells, further research on the mechanism involved in IRinduced apoptosis is essential for development of therapeutic approaches for oral SCC.

\section{Acknowledgments}

This work was supported by grants from National Natural Science Foundations of China (№ 81072202 and 30772269). Authors especially thank Prof Yan HOU for her excellent tech- nical assistance.

\section{Author contribution}

Xiao-ying ZHANG, Xun QU, Shan-zhen SUN, and Feng-cai WEI designed the research; Xiao-ying ZHANG and Gui-xiang LIU performed research; Cheng-qin WANG and Cheng-jun ZHOU contributed analytic tools; Xiao-ying ZHANG analysed data and wrote the paper.

\section{References}

1 Rodrigues VC, Moss SM, Tuomainen H. Oral cancer in the UK: to screen or not to screen. Oral Oncol 1998; 34: 454-65.

2 Greenlee RT, Hill-Harmon MB, Murray T, Thun M. Cancer statistics, 2001. CA Cancer J Clin 2001; 51: 15-36.

3 Jackel MC, Ambrosch P, Christiansen H, Martin A, Steiner W. Value of postoperative radiotherapy in patients with pathologic N1 neck disease. Head Neck 2008; 30: 875-82.

4 Lal A, Gorospe M. Egad, more forms of gene regulation: the gadd45a story. Cell Cycle 2006; 5: 1422-5.

5 Fornace AJ Jr, Alamo I Jr, Hollander MC. DNA damage-inducible transcripts in mammalian cells. Proc Natl Acad Sci USA 1988; 85: 8800-4.

6 Papathanasiou MA, Kerr NC, Robbins JH, McBride OW, Alamo I Jr, Barrett SF, et al. Induction by ionizing radiation of the gadd45 gene in cultured human cells: lack of mediation by protein kinase C. Mol Cell Biol 1991; 11: 1009-16.

7 Hollander MC, Alamo I, Jackman J, Wang MG, McBride OW, Fornace AJ Jr. Analysis of the mammalian gadd45 gene and its response to DNA damage. J Biol Chem 1993; 268: 24385-93.

8 Shain SA. Exogenous fibroblast growth factors maintain viability, promote proliferation, and suppress GADD45alpha and GAS6 transcript content of prostate cancer cells genetically modified to lack endogenous FGF-2. Mol Cancer Res 2004; 2: 653-61.

9 Bower JJ, Leonard SS, Chen F, Shi X. As(III) transcriptionally activates the gadd45a gene via the formation of $\mathrm{H}_{2} \mathrm{O}_{2}$. Free Radic Biol Med 2006; 41: 285-94.

10 Corn PG, El-Deiry WS. Microarray analysis of p53-dependent gene expression in response to hypoxia and DNA damage. Cancer Biol Ther 2007; 6: 1858-66.

11 Rosemary Siafakas A, Richardson DR. Growth arrest and DNA damage-45 alpha (GADD45alpha). Int J Biochem Cell Biol 2009; 41: 986-9.

12 Smith ML, Ford JM, Hollander MC, Bortnick RA, Amundson SA, Seo YR, et al. p53-mediated DNA repair responses to UV radiation: studies of mouse cells lacking p53, p21, and/or gadd45 genes. Mol Cell Biol 2000; 20: 3705-14.

13 Hollander MC, Sheikh MS, Bulavin DV, Lundgren K, Augeri-Henmueller L, Shehee R, et al. Genomic instability in Gadd45a-deficient mice. Nat Genet 1999; 23: 176-84.

14 Harkin DP, Bean JM, Miklos D, Song YH, Truong VB, Englert C, et al. Induction of GADD45 and JNK/SAPK-dependent apoptosis following inducible expression of BRCA1. Cell 1999; 97: 575-86.

15 Tran H, Brunet A, Grenier JM, Datta SR, Fornace AJ Jr, DiStefano PS, et al. DNA repair pathway stimulated by the forkhead transcription factor FOX03a through the Gadd45 protein. Science 2002; 296: 530-4.

16 Tront JS, Hoffman B, Liebermann DA. Gadd45a suppresses Ras-driven mammary tumorigenesis by activation of c-Jun $\mathrm{NH}_{2}$-terminal kinase and p38 stress signaling resulting in apoptosis and senescence. Cancer Res 2006; 66: 8448-54.

17 Tong T, Ji J, Jin S, Li X, Fan W, Song Y, et al. Gadd45a expression induces Bim dissociation from the cytoskeleton and translocation to 
mitochondria. Mol Cell Biol 2005; 25: 4488-500.

18 Azria D, Larbouret C, Cunat S, Ozsahin M, Gourgou S, Martineau P, et al. Letrozole sensitizes breast cancer cells to ionizing radiation. Breast Cancer Res 2005; 7: R156-63.

19 D'Silva NJ, Ward BB. Tissue biomarkers for diagnosis \& management of oral squamous cell carcinoma. Alpha Omegan 2007; 100: 182-9.

20 Palme CE, Gullane PJ, Gilbert RW. Current treatment options in squamous cell carcinoma of the oral cavity. Surg Oncol Clin N Am 2004; 13: 47-70.

21 Jang WI, Wu HG, Park Cl, Kim KH, Sung MW, Kim MJ, et al. Treatment of patients with clinically lymph node-negative squamous cell carcinoma of the oral cavity. Jpn J Clin Oncol 2008; 38: 395-401.

22 Chambers MS, Garden AS, Kies MS, Martin JW. Radiation-induced xerostomia in patients with head and neck cancer: pathogenesis, impact on quality of life, and management. Head Neck 2004; 26 : 796-807.

23 Benjamin CL, Melnikova VO, Ananthaswamy HN. P53 protein and pathogenesis of melanoma and nonmelanoma skin cancer. Adv Exp Med Biol 2008; 624: 265-82.

24 Daino K, Ichimura S, Nenoi M. Early induction of CDKN1A (p21) and GADD45 mRNA by a low dose of ionizing radiation is due to their dose-dependent post-transcriptional regulation. Radiat Res 2002; 157: 478-82.

25 Amundson SA, Lee RA, Koch-Paiz CA, Bittner ML, Meltzer P, Trent JM, et al. Differential responses of stress genes to low dose-rate gamma irradiation. Mol Cancer Res 2003; 1: 445-52.

26 Takekawa M, Saito H. A family of stress-inducible GADD45-like proteins mediate activation of the stress-responsive MTK1/MEKK4 MAPKKK. Cell 1998; 95: 521-30.

27 Perugini M, Kok CH, Brown AL, Wilkinson CR, Salerno DG, Young SM, et al. Repression of Gadd45alpha by activated FLT3 and GMCSF receptor mutants contributes to growth, survival and blocked differentiation. Leukemia 2009; 23: 729-38.

28 Zhang W, Hoffman B, Liebermann DA. Ectopic expression of MyD118/ Gadd45/CR6 (Gadd45beta/alpha/gamma) sensitizes neoplastic cells to genotoxic stress-induced apoptosis. Int J Oncol 2001; 18: 749-57.

29 Lu X, Yang C, Hill R, Yin C, Hollander MC, Fornace AJ Jr, et al. Inactivation of gadd45a sensitizes epithelial cancer cells to ionizing radiation in vivo resulting in prolonged survival. Cancer Res 2008; 68: 357983.

30 Zerbini LF, Libermann TA. GADD45 deregulation in cancer: frequently methylated tumor suppressors and potential therapeutic targets. Clin Cancer Res 2005; 11: 6409-13.

31 Al-Romaih K, Sadikovic B, Yoshimoto M, Wang Y, Zielenska M, Squire JA. Decitabine-induced demethylation of 5' CpG island in GADD45A leads to apoptosis in osteosarcoma cells. Neoplasia 2008; 10: 47180. 